\title{
EFFECTS OF PHOSPHOLIPID COMPOSITION ON ADJUVANT EFFICIENCY OF LIPOSOMES
}

\author{
J. HAMPL, J. FRANZ, K. JORDÁNOVÁ*, and J. ŠTĚPÁNEK \\ Veterinary Research Institute, 62132 Brno \\ *Faculty of Sciences, Masaryk University, Brno \\ Received January 18, 1995 \\ Accepted May 30, 1995
}

\begin{abstract}
H a m pl J., J. Fra n z, K. J or dá n o vá, J. Š tě pá n e k: Effects of Phospholipid Composition on Adjuvant Efficiency of Liposomes. Acta vet. Brno 1995, 64: 163-164.

Phospholipids with various transition temperatures, including egg phosphatidyl lecithine (EPL), hydrogenated egg phosphatidyl lecithine (HEPL), dimyristoyl phosphatidylcholine (DMPC) and dipalmitoyl phosphatidylcholine (DPPC), and cholesterol (C), stearylamine (SA) and dicetylphosphate (DCP) were used in various molar proportions for the preparation of multilamellar liposomes by the dehydration-rehydration method. BALB/c mice were then immunized and reimmunized with BSA entrapped in the liposomes. No significant effects of transition temperatures of the phospholipids or of surface charge on the intensity of antibody responses were demonstrable. The strongest antibody responses were found in mice immunized with multilamellar liposomes containing in their structures EPL, HEPL or DMPC combined with C, DCP and/or SA, which also showed a high entrapment stability when incubated in vitro in blood serum.
\end{abstract}

Liposomes, BSA, antibody response, transition temperature, surface charge, stability

Advances in biochemical and biotechnological methods have provided a basis for the development of new generations of biologicals including subunit vaccines and vaccines containing highly purified, inactivated microorganisms. However, the immunogenicity of this class of vaccines is often insufficient. One of the ways how to overcome this drawback is simultaneous administration of effective adjuvants or immunomodulants.

It has been well established that liposomes can enhance immune responses to a number of microbial antigens. Currently, they are becoming one of the few non-toxic, biologically degradable adjuvants with prospective uses in human and veterinary medicine (A $1 \mathrm{v}$ i n $\mathrm{g}$ and R i c h ard s 1990; G r e g o ri ad is 1990; Frie de et al. 1994). There exist several ways of modulating of the adjuvant activity of liposomes, including modifications of phospholipid composition allowing the introduction of surface charge or influencing the fluidity of the phospholipid bilayer, or control of morphological structure by various preparative procedures ( $\mathrm{V}$ a n $\mathrm{H}$ o u t e et al. 1981; G r e g o r i a d i s et al. 1987; Gregoriadis and Panagiotidi 1989; Gabizon and Papahadjopoulos 1992; B akker-Woudenberg et al. 1993a; Fortin and Therien 1993; Charles et al. 1994).

The object of our investigations were immune responses in mice treated with BSA as a model antigen entrapped in multilamellar liposomes prepared from phospholipids with various transition temperatures $(\mathrm{Tc})$ and different surface charges.

\section{Chemicals}

\section{Materials and Methods}

Egg phosphatidyl lecithine (E 80) - EPL and hydrogenated egg phosphatidyl lecithine - HEPL supplied by Lipoid K.G.; dimyristoyl phosphatidylcholine - DMPC, dipalmitoyl phosphatidylcholine - DPPC, stearylamine - SA, dicetylphosphate - DCP, and tetramethyl benzidine supplied by Sigma; cholesterol - $\mathrm{C}$ and bovine serum albumin - BSA supplied by Flow and ÚSOL, Prague, respectively. 
Preparation of liposomes and entrapment of BSA

Multilamellar liposomes (MLV) were prepared as described by $\mathrm{K}$ i r b y and $\mathrm{G} \mathrm{r} \mathrm{e} \mathrm{g} \mathrm{o} \mathrm{r} \mathrm{i} \mathrm{a} \mathrm{d} \mathrm{is} \mathrm{(1984)} \mathrm{in} \mathrm{four}$ variants based on EPL (Tc approx. $\left.-15^{\circ} \mathrm{C}\right)$, HEPL $\left(\mathrm{Tc}=54^{\circ} \mathrm{C}\right)$, DMPC $\left(\mathrm{Tc}=23^{\circ} \mathrm{C}\right)$, and DPPC $\left(\mathrm{Tc}=45^{\circ} \mathrm{C}\right)$, respectively. Each of the phospholipids was used alone or in compositions with $\mathrm{C}$ at molar ratios 0.8:0.2 or 0.5:0.5, or with SA and DCP at the molar ratio 0.45:0.45:0.1. The initial weight ratio of the phospholipid composition and BSA was invariably 100:1. The preparation of liposomes from phospholipids with above-zero Tc was made at temperatures by 2 to $3{ }^{\circ} \mathrm{C}$ higher than was the declared Tc.

BSA labelled with ${ }^{125}$ I by the oxidative method with chloramine $\mathrm{T}$ ( $\mathrm{H} \mathrm{u}$ t e r and $\mathrm{G} \mathrm{r}$ e e $\mathrm{n}$ w o o d 1962) was used as a tracer for the determination of the rate of entrapment of BSA into MLV and in entrapment stability tests.

\section{Entrapment stability tests}

The following compositions with the highest BSA entrapment rates and surface charges were selected from each of the MLV variants to be tested for the entrapment stability:

Variant $1:$ EPL-C-DCP

Variant 2 : HEPL-C-SA

Variant 3 : DMPC-C-SA

Variant 4 : DPPC-C-SA

All tests were made at $22^{\circ} \mathrm{C}$ in triplicates. The liposomal suspensions were incubated in PBS, goat serum diluted 1:1 with PBS, or isotonic glycerol solution for 24 hours and centrifugated (Beckman, rotor SW 55 $\mathrm{Ti}, 40,000$ r.p.m., $30 \mathrm{~min}$ ) after 2,4 and 24 hours of incubation. Radioactivity of the ${ }^{125}$ I-labelled BSA was measured in aliquots of supernatants, the aliquots were then quantitatively returned to the respective centrifugation vessels and the liposomal pellets were resuspended after each centrifugation $(\mathrm{H} \mathrm{a} \mathrm{m} \mathrm{pl}$ et al. 1994).

Im munization

Seventy BALB/c mice were divided into four experimental and one control groups. Each experimental group was treated with one of the variants of MLV showing the highest entrapment rate and surface charge (see above). The uniform dose was 2 ug BSA intraperitoneally per animal for both the primary immunization and reimmunization made after 3 weeks.

The immunization scheme was as follows:

\begin{tabular}{ll}
\hline Group & \multicolumn{1}{c}{ Treatment } \\
\hline 1 & BSA entrapped in EPL-C-DCP liposomes \\
2 & BSA entrapped in HEPL-C-SA liposomes \\
3 & BSA entrapped in DMPC-C-SA liposomes \\
4 & BSA entrapped in DPPC-C-SA liposomes \\
control & free BSA in PBS \\
\hline
\end{tabular}

Three mice of each group were sacrificed on experimental days $21,35,49$, and 63 and blood was collected for serological examinations.

Serology

Antibodies to BSA were determined by the conventional indirect ELISA using polystyrene microtitre plates, porcine antibodies to murine IgG purified by affinity chromatography and labelled with horse-radish peroxidase as the conjugate, and hydrogen peroxide and tetramethyl benzidine as the substrate. All the tests were made in duplicates in dilution series starting from 1:100.

\section{Results}

The effects of various phospholipid compositions on the entrapment of BSA into MLV are summarized in Table 1. 
Table 1

Entrapment of BSA into liposomes

\begin{tabular}{|c|c|c|c|c|}
\hline Variant & $\begin{array}{l}\text { Phospholipid } \\
\text { composition }\end{array}$ & Molar ratio & $\begin{array}{c}\text { Entrapment rate } \\
(\%)\end{array}$ & $\mathrm{n}$ \\
\hline I & $\begin{array}{l}\text { EPL } \\
\text { EPL:C } \\
\text { EPL:C } \\
\text { EPL:C:SA } \\
\text { EPL:C:DCP }\end{array}$ & $\begin{array}{l}0.8: 0: 2 \\
0.5: 0.5 \\
0.45: 0.45: 0.1 \\
0.45: 0.45: 0.1\end{array}$ & $\begin{array}{l}10 \pm 1 \\
39 \pm 4 \\
36 \pm 2 \\
32 \pm 3 \\
45 \pm 1\end{array}$ & $\begin{array}{l}4 \\
4 \\
4 \\
8 \\
8\end{array}$ \\
\hline II & $\begin{array}{l}\text { HEPL } \\
\text { HEPL:C } \\
\text { HEPL:C } \\
\text { HEPL:C:SA } \\
\text { HEPL:C:DCP }\end{array}$ & $\begin{array}{l}0.8: 0.2 \\
0.5: 0.5 \\
0.45: 0.45: 0.1 \\
0.45: 0.45: 0.1\end{array}$ & $\begin{array}{l}11 \pm 1 \\
19 \pm 4 \\
23 \pm 2 \\
57 \pm 3 \\
34 \pm 2\end{array}$ & $\begin{array}{l}4 \\
4 \\
4 \\
4 \\
4\end{array}$ \\
\hline III & $\begin{array}{l}\text { DMPC } \\
\text { DMPC:C } \\
\text { DMPC:C } \\
\text { DMPC:C:SA } \\
\text { DMPC:C:DCP }\end{array}$ & $\begin{array}{l}0.8: 0.2 \\
0.5: 0.5 \\
0.45: 0.45: 0.1 \\
0.45: 0.45: 0.1\end{array}$ & $\begin{array}{l}10 \pm 1 \\
13 \pm 1 \\
20 \pm 1 \\
36 \pm 3 \\
27 \pm 3\end{array}$ & $\begin{array}{l}4 \\
4 \\
4 \\
4 \\
4\end{array}$ \\
\hline IV & $\begin{array}{l}\text { DPPC } \\
\text { DPPC:C } \\
\text { DPCC:C } \\
\text { DPPC:C:SA } \\
\text { DPPC:C:DCP }\end{array}$ & $\begin{array}{l}0.8: 0.2 \\
0.5: 0.5 \\
0.45: 0.45: 0.1 \\
0.45: 0.45: 0.1\end{array}$ & $\begin{array}{l}10 \pm 1 \\
13 \pm 1 \\
24 \pm 5 \\
38 \pm 3 \\
31 \pm 4\end{array}$ & $\begin{array}{l}4 \\
4 \\
4 \\
4 \\
4\end{array}$ \\
\hline
\end{tabular}

It is evident that the highest entrapment rate ( $57 \%)$ was obtained with the composition HEPL-C-SA $=0.45: 0: 45: 0.1$. Stearylamine, providing the liposomes with surface charge, increased also the rate of entrapment into liposomes prepared from synthetic saturated phospholipids (DMPC 36\%; DPPC 38\%). Up to three - and fivefold differences between the minimal and the maximal entrapment rates were found in liposomes prepared from DMPC or DPPC and HEPL, respectively. The lowest entrapment rates were found invariably in liposomes prepared from the basic phospholipids alone. DCP and $\mathrm{C}$ had favourable effects on entrapment rate also in liposomes prepared from EPL.

Results of BSA entrapment stability tests are presented in Tables 2 through 4 . The highest stability was found in HEPL-based liposomes (Variant 2) irrespective of the incubation medium. On the other hand, the lowest stability and highest release of BSA into the medium were found in the DPPC-based liposomes (Variant 4). Isotonic glycerol solution and PBS

Table 2

Released BSA from liposomes during incubation in blood serum Percentage of entrapped BSA

\begin{tabular}{|llllll|}
\hline Variant & $\mathrm{n}$ & 0 & Time (hours) & \\
& & 100 & 2 & 4 & 24 \\
\hline 1 & 3 & 100 & 92 & 91 & 89 \\
2 & 3 & 100 & 97 & 97 & 96 \\
3 & 3 & 100 & 94 & 83 & 79 \\
4 & 3 & 96 & 92 & 70 \\
\hline
\end{tabular}


Table 3

Release of BSA from liposomes during incubation in glycerol Percentage of entrappe d BSA

\begin{tabular}{|c|c|c|c|c|c|}
\hline Variant & $\mathrm{n}$ & 0 & & 4 & 24 \\
\hline 1 & 3 & 100 & 93 & 90 & 82 \\
\hline 2 & 3 & 100 & 99 & 98 & 98 \\
\hline 3 & 3 & 100 & 98 & 98 & 98 \\
\hline 4 & 3 & 100 & 97 & 96 & 87 \\
\hline
\end{tabular}

Table 4

Release of BSA from liposomes during incubation in PBS Percentage of entrapped BSA

\begin{tabular}{|c|c|c|c|c|c|}
\hline Variant & $\mathrm{n}$ & 0 & & 4 & 24 \\
\hline 1 & 3 & 100 & 95 & 95 & 89 \\
\hline 2 & 3 & 100 & 98 & 98 & 98 \\
\hline 3 & 3 & 100 & 94 & 94 & 93 \\
\hline 4 & 3 & 100 & 99 & 98 & 80 \\
\hline
\end{tabular}

proved to be suitable media for the preparation and maintenance of liposomal suspensions reconstituted from freeze-dried staff at least four hours. The release of BSA did not exceed $6 \%$ in any of the compositions.

Immunization experiments were conducted with MLV with various phospholipid compositions tested for entrapment stability. All the experimental groups were treated with the uniform dose $2 \mu \mathrm{g}$ BSA. Control mice received the same dose of free BSA.

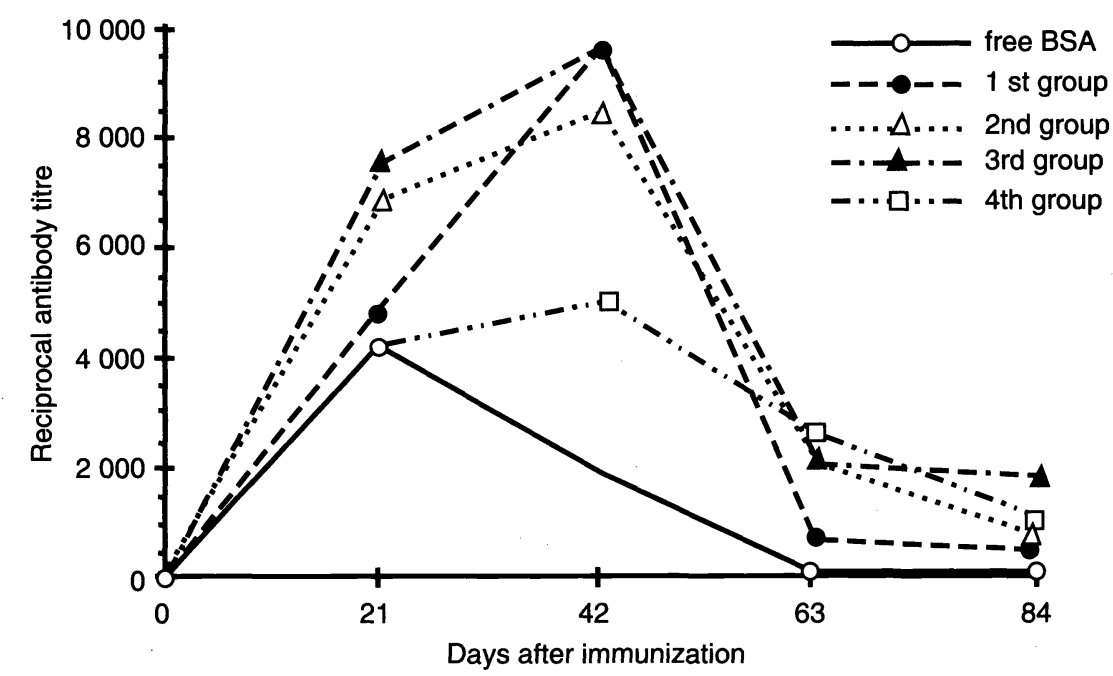

Fig. 1 Antibody response of mice after immunization and reimmunizatoin with BSA liposomes Legend: Immunization Day 0

Reimmunization Day 21 
Expectably, the weakest antibody responses were recorded at each sampling in the control group. No significant differences in antibody titres were observed among the Groups 1 - 3.

The primary antigenic stimulation was followed by an increase of antibody titres in all the groups including controls. The reimmunization resulted in a further marked increase in Groups $1-3$, but was followed by a decrease in controls. Low antibody levels were demonstrable in all the experimental groups at the end of the observation period, i.e. on Day 84 (Fig. 1).

\section{Discussion}

It is well known that liposomes can be used as excipients for various macromolecular substances, such as proteins, nucleic acids, enzymes or hormones, as well as for drugs, including antibiotics (S a to and S u n m o to 1992; Gre goriad is and Fl ore n ce 1993; B a k ke r - W oude n ber g et al. 1993b).

The entrapment rate can be increased and the release into the environment modulated by modifying the composition, fluidity, morphology and surface properties of the phospholipid bilayer of liposomes (K i r b y and G re g or i a d is 1984; G r e g or i a d is 1990; The rien et al. 1991).

The entrapment of BSA as a model antigen into multilamellar liposomes prepared from saturated phospholipids or one phospholipid containing in its structure unsaturated fatty acids was tested in our experiments. Transition temperatures of the phospholipids were chosen to exceed (DPPC, HEPL) or to be lower (EPL, DMPC) than body temperature of the immunized animals. However, the actual Tc were different owing to the inclusion of cholesterol, dicetyl phosphate and/or stearylamine into the respective phospholipid composition.

It is evident from the results of the entrapment experiments that the rate of BSA entrapment depends rather on surface charge and the presence of cholesterol than on Tc of phospholipids. Although the highest entrapment rates of individual variants of multilamellar liposomes ranged between 36 and $57 \%$, it is evident that positive surface charge is decisive in saturated phospholipids.

Similarly as other authors, we could demonstrate favourable effects of higher molar proportions of cholesterol on the entrapment rate and also confirm the direct proportionality between the length of fatty acid chain in the phospholipid molecule and the rate of entrapment of hydrophilic substances as reported by B e $t$ a g e r i (1993).

Our immunization experiment with MLV were made to reveal possible dependence of antibody responses on Tc or surface charge. Available data concerning this dependence are controversial. Thus Gre goriad is etal. (1987) and Davis and Gre goriad is (1987) reported strong and negligible antibody responses in mice immunized with tetanus toxoid entrapped in liposomes prepared from phospholipids with low (EPC) and high (DSPC, $54^{\circ} \mathrm{C}$ ) $\mathrm{Tc}$, respectively. In another of their papers, $\mathrm{G}$ r e g o r i a d is et al. (1992) reported similar antibody responses to influenza membrane antigen entrapped in liposomes prepared from EPC or DSPC. The same conclusion was arrived at by $\mathrm{Gr}$ e $\mathrm{g}$ or i a d is and $\mathrm{Pa}$ a ag i o t i d i (1989) who immunized mice with BSA. K in s k y (1978) and B a k o u c he and $\mathrm{G}$ e r 1 i e r (1986), who used other membrane antigens, found stronger immune responses in mice treated with liposomes prepared from phospholipids with higher Tc.

A l p a r et al. (1992) confirmed that adjuvant effects of DSPC-C liposomes were superior to those of aluminium hydroxide in guinea pigs immunized with tetanus toxoid.

$\mathrm{Cl}$ a r k e and S t o k e s (1992), who immunized mice intraperitoneally with egg albumin 
entrapped in DPPC-C-DCP or EPC-S-DPC liposomes found stronger antibody responses in the former. However, the latter liposomes were more effective when administered orally.

Antibody responses depend apparently rather on the properties of antigen and mode of its entrapment in liposomes than on Tc of phospholipids and fluidity of the liposomal bilayer ( $\mathrm{S} \mathrm{h} \mathrm{a} \mathrm{h} \mathrm{u} \mathrm{m}$ and T h e r i e $\mathrm{n} \mathrm{1994).} \mathrm{The} \mathrm{effects} \mathrm{of} \mathrm{fluidity} \mathrm{on} \mathrm{liposome} \mathrm{degradation} \mathrm{was}$ demonstrated, among others, by $\mathrm{N}$ a $\mathrm{g}$ a y a s u et al. (1994) who administered daunorubicin, entrapped in EPC-C-DCP or HEPC-C-DCP liposomes to rats affected by Yoshida sarcoma and observed therapeutic effects only in those treated with HEPC liposomes.

In our experiments, the antibody responses in mice treated with the EPL-, HEPL- or DMPC-based liposomes were similar and no effects of Tc were demonstrable. Thereby it was also confirmed that surface charge is decisive. While the HEPL- and DMPC-based liposomes carried positive surface charge as a results of the presence of SA, DCP provided the EPL-based liposomes with negative surface charge.

The entrapment stability tests, which were made by 24-hour incubation in PBS, isotonic glycerol solution or blood serum, yielded the highest values of 96 to $98 \%$ in HEPL-based liposomes and the lowest ones of 70 to $87 \%$ in DPPC-based liposomes. In both cases, the lower values pertained to the incubation in blood serum as a biological medium. This fact apparently influenced the results of the immunization experiments. DPPC-based liposomes, which, in a biological environment, release rapidly the entrapped antigen, do not fulfil their depot function in the optimal manner, as confirmed also by the weakest responses to both the first and the repeated treatments in mice.

\section{Vliv různé fosfolipidní kompozice liposomů na jejich adjuvantní účinnost}

K př́pravě multilamelárních liposomů metodou dehydratace - rehydratace byly použity fosfolipidy $\mathrm{s}$ různou tranzitní teplotou (Tc), a to vaječný fosfatidyl lecitin (EPL), hydrogenovaný vaječný fosfatidyl lecitin (HEPL), dimyristoyl fosfatidylcholin (DMPC), dipalmitoyl fosfatidylcholin (DPPC), dále cholesterol (C), stearylamin (SA) a dicetylfosfát (DCP) v různých molárních poměrech. Liposomy s inkorporovaným BSA byly použity $\mathrm{k}$ intraperitoneální imunizaci a reimunizaci BALB/c myší.

$\mathrm{Z}$ výsledků imunizačního pokusu vyplynulo, že tranzitní teplota $(\mathrm{Tc})$ fosfolipidů ani povrchový náboj liposomů neovlivnil zásadně tvorbu protilátek. Nejvyšší protilátková odpověd byla zjištěna po imunizaci multilamelárními liposomy připravenými z EPL, HEPL a DMPC, C a DCP, resp. SA, u nichž byla v pokuse in vitro zjištěna vyšší stabilita při inkubaci v krevním séru.

\section{References}

ALPAR H. O., BOWEN J. C., BROWN M. R. W. 1992: Effectiveness of liposomes as adjuvants of orally and nasally administered tetanus toxoid. Int. J. Pharm. 88:335-344

ALVING C. R., RICHARDS R. L. 1990: Liposomes containing lipid A: a potent nontoxic adjuvant for a human malaria sporozoite vaccine. Immunol. Letters 25: 275-280

ALVING C. R. 1992: Immunologic aspects of liposomes: presentation and processing of liposomal protein and phospholipid antigens. Biochim. Biophys. Acta 1113:307-322

BAKKER-WOUDENBERG I. A. J. M., LOKERSE A. F. - ten KATE M. T., MELISSEN P. M. B., van VIANEN W., van ETTEN E. W. M. 1993a: Liposomes as carriers of antimicrobial agents or immunomodulatory agents in the treatment of infections. Eur. J. clin. Microbiol. infect. Dis. 1:61-67

BAKKER-WOUDENBER G I. A. J. M.- LOKERSE A. F. - ten KATE M. T. - MOUTON J. W. - WOODLE M. C. - STORM G. 1993b: Liposomes with prolonged blood circulation and selective localization in Klebsiella pneumoniae-infected lung tissue. J. inf. Dis. 168:164-171 
BAKOUCHE O., GERLIER P. 1986 : Presentation of an MuLV-related tumour antigen in liposomes as a potent tertiary immunogen after adoptive transfer. Immunology 57:219-223

BETAGERI G. V. 1993: Liposomal encapsulation and stability of dideoxyinosine triphosphate. Drug Develop. Ind. Pharm. 19:531-539

CHARLES S. D., HUSSAIN I., CHEONG-UPCHOI, NAGARAJA K. V., SIVANANDAN V. 1994: Adjuvanted subunit vaccines for the control of Salmonella enteritidis infection in turkeys. Am. J. Vet. Res. 55:636-642

CLARKE C. J., STOKES C. R. 1992: The intestinal and serum humoral immune response of mice to systemically and orally administered antigens in liposomes: I. The response to liposome - entrapped soluble proteins. Vet. Immunol. Immuno-pathol. 32:125-138

DAVIS D., GREGORIADIS G. 1987 : Liposomes as adjuvants with immunopurified tetanus toxoid: influence of liposomal characteristics. Immunology 61:229-234

FRIEDE M., MULLER S., BRIAND J.P., PLAUE S., FERNANDES I., FRISCH B., SCHUBER F., Van REGENMORTEL M. H. V. 1994: Selective induction of protection against influenza virus infection in mice by a lipid-peptide conjugate delivered in liposomes. Vaccine 12:791-797

FORTIN A., THÉRIEN H. M. 1993: Mechanism of liposome adjuvanticity: an in vivo approach. Immunobiol. 188:316-322

GABIZON A., PAPAHADJOPOULOS D. 1992 : The role of surface charge and hydrophilic groups on liposome clearance in vivo. Biochim. Biophys. Acta 1103:94-100

GREGORIADIS G. 1990: Immunological adjuvants: a role for liposomes. Immunol. Today 11:89-97

GREGORIADIS G., DAVIS D., DAVIES A. 1987 : Liposomes as immunological adjuvants: antigen incorporation studies. Vaccine 5:145-151

GREGORIADIS G., FLORENCE A. T. 1993 : Liposomes in drug delivery. Clinical, diagnostic and ophthalmic potential. Drugs 45:15-28

GREGORIADIS G., PANAGIOTIDI Ch. 1989: Immunoadjuvant action of liposomes: comparison with other adjuvants. Immunol. Letters 20:237-240

GREGORIADIS G., TAN L., AHMEIDA B. E. T. S., JENNINGS R. 1992: Liposomes enhance the immunogenicity of reconstituted influenza virus $A / P R / 8$ envelopes and the formation of protective antibody by influenza virus A/Sichuan/87 (H3N2) surface antigen. Vaccine 10:747-753

HAMPL J., HERZIG I., VLČEK J. 1994 : Pharmacokinetics of sodium humate in chickens. Vet. Med.-Czech, 39:305-313

HUNTER W. M., GREENWOOD F. C. 1962: Preparation of iodine 131-labelled growth hormone of high specific activity. Nature 194:495-496

KINSKY S. C. 1978: Immunogenicity of liposomal model membranes. Ann. N. Y. Acad. Sci. 308:111-123

KIRBY Ch., GREGORIADIS G. 1984: Dehydration-rehydration vesicles: a simple method for high yield drug entrapment in liposomes. Biotechnology 11:979-984

NAGAYASU A., SHIMOOKO T., KINOUCHI Y., UCHIYAMO K., TAKEICHI V., KIWODO H. 1994: Effects of fluidity and vesicle size on antitumor activity and myelosuppressive activity of liposomes loaded with daunorubicin. Biol. Pharm. Bull. 17:935-939

SATO T., SUNAMOTO J. 1992: Recent aspects in the use of liposomes in biotechnology and medicine. Prog. Lipid Res. 31:345-372

SHAHUM E., THERIEN H. M. 1994 : Correlation between in vitro and in vivo behaviour of liposomal antigens. Vaccine 12:1125-1131

THERIEN H. M., SHAHUM E., FORTIN A. 1991: Liposome adjuvanticity: influence of dose and protein:lipid ratio on the hmoral response to encapsulated and surface-linked antigen. Cell. Immunol. 136:402-413

Van HOUTE A. J., SNIPPE H., SCHMITZ M., WILLER J. 1981: Characterization of immunogenic properties of haptenated liposomal model membranes in mice. V. Effect of membrane composition on humoral and cellular immunogenicity. Immunology 44:561-568 